\title{
ETHNICITY, CULTURAL IDENTITY AND BORDERING: A TORNEDALIAN NEGRO
}

\author{
Anne Heith
}

\begin{abstract}
This article examines how experiences of internal colonialism may be expressed in literary writing, through an analysis of Bengt Pohjanen's poem Rättipäät (Ragheads). The article discusses the poem and its embedding in a Meänkieli (Tornedalian Finnish) grammar book, Meänkielen kramatiikki (Pohjanen \& Kenttä 1996). The theme explored is the tensions arising between homogenising modernity in a Swedish nation-building context and the particular situation of the Tornedalian Finnish minority in northern Sweden. Colonial complicity and vernacular cosmopolitanism are key concepts used in describing these tensions. The article proposes that the poem represents a remapping of the 'national' and the 'international' as allegiances are established between the Swedish national minority of the Tornedalians and migrants in European metropolitan centres. Hence the Tornedalians in the northern borderlands are presented as symbolic citizens in new migrant cartographies. This implies that a new myth of belonging is created, which unifies national minorities with metropolitan migrants.
\end{abstract}

Keywords: Swedish Tornedalians, minority status, Meänkieli, internal colonialism, colonial complicity, vernacular cosmopolitanism

From the vantage point of the political and administrative centre of the Swedish nation-state located in the area of Stockholm, the Tornedalian borderlands up in the north have always been regarded as a marginal and culturally alien territory inhabited by the Sámi people and Tornedalian Finns. The idea of a northern fringe of the nation-state was enhanced after Sweden lost Finland at the conclusion of the 1808-09 war with Russia. The peace treaty resulted in the border of 1809, which separates Sweden and Finland in the Torne Valley. The Tornedalian Finns on both sides of the border rivers consequently became citizens of different states. During the period that followed, there was a fear amongst the Swedish elite of Russian expansionism. Finland, which had become a Russian Grand Duchy, was seen as a space from where potential threats to Swedish sovereignty might emerge (Åselius 1994; Rodell 2009). From a perspective based on the notion of the geographical centre of the Mälardal region as a norm for national culture, the Finno-Ugric peoples of the sparsely populated north constituted a strange element in the national imagined community (cf. Anderson 2006). 
Another factor contributing to the 'othering' of the Tornedalians is the compliance between modernisation and cultural homogenisation, which characterises Swedish twentieth century social development (Arvastson 1999). The attribution of 'strangeness' to the Tornedalian Finns in Sweden may be related to their minority status due to Finno-Ugric ethnicity in a Swedish nation-state context, and additionally to the use of a minority language, Meänkieli, previously called Tornedalian Finnish, as well as to their customs, culture and mentality. These factors contributed to the construction of the Tornedalians as the 'other' in pedagogies that created distinguishing markers between modernity and progress and its 'other'. During the building of the modern Swedish welfare state, the political elite actively promoted the notion of a modern society as a goal to be realised. In the $1930 \mathrm{~s}$, the popular revivalist Korpela movement captured people's minds in the Swedish Torne Valley; however, this led to tragedies when people got rid of all their earthly possessions while waiting for an ark. They firmly believed that an ark would arrive and save them as the world came to an end. National newspaper journalists from the south of Sweden reported the irrationality of the Korpelians (Lundmark 1985). In their reports religious fervour, irrationalism, a marginal northern location and Finno-Ugric ethnicity, together with customs and a culture incompatible with a modern, enlightened society, are highlighted as "the soil where craziness thrives" (Heith 2009a). This exemplifies how conceptual borders were constructed with the effect that the modern community of the Swedish nation-state was distinguished from its peripheral 'others'. This example of the Korpela movement and its role as a marker of difference indicates how local, popular revivalist movements were used to create diacritical borders that distinguished 'us' from 'them'. Another, better-known movement is that of Laestadianism, which has been described as an arena for expressing Finno-Ugric ethnicity, for example among the Kvens of northern Norway (Kristensen 1998; Sundelin 1998).

\section{THE COLONIAL PAST VIEWED FROM AN ANTI- AND POST-COLONIAL PRESENT}

This article concentrates on how a history of marginalisation has affected the Swedish Tornedalians through the analysis of a specimen of literary writing, produced by the Swedish Tornedalian cultural mobiliser and author Bengt Pohjanen (b. 1944). One argument of this article is that the strategy, which is being performed in Bengt Pohjanen's poem Rättipäät, may be seen as a component of the kind of vernacular cosmopolitanism discussed by Bhabha 
(2008: IX-XXV). The analysis is based on a close reading of Rättipäät, literally Ragheads. 'Internal colonialism', 'othering', 'colonial complicity' and 'vernacular cosmopolitanism' are concepts that are used in order to highlight the ongoing negotiations between the past and the present, which shape Pohjanen's depiction of how the colonial past affects the anti-colonial and post-colonial present. The question that is addressed is how the past is present in contemporary cultural mobilisation and how it is transformed when regarded from within conceptual frameworks critical of a history of culturally homogenising modernity. A theme that is discussed is how the kind of critical positioning exemplified by Bengt Pohjanen contributes to a deconstruction of the narrations of the nation as "the many as one" (cf. Bhabha 2008: 222). This involves the conjuring up of alternative national pedagogies, thus acknowledging the histories and experiences of historical, ethnic and linguistic minorities within the nation-state.

In order to account for processes whereby ethnic minorities have been excluded from the Nordic narratives of the nation, the concept of 'colonial complicity' has been developed by researchers who critically examine connections between race, ethnicity and gender, on the one hand, and notions of a modern, progressive nation, on the other (Keskinen et al. 2009; Vuorela 2009):

This theoretical approach investigates the fractures in Nordic whiteness discourses where the construction of (exclusive) national identities is built upon a notion of belonging grounded in 'race'/ethnicity and where distinctions, such as the one between 'the nation' and 'the immigrants', are systematically created and reinforced. [. . .] [T] his collection [Complying with Colonialism: Gender, Race and Ethnicity in the Nordic Region] explores ways of thinking about the relationship between the welfare state and its gendered and racialised 'others'. (Keskinen et al. 2009: 3-4)

The historical exclusion of the Finno-Ugric Tornedalian minority in Swedish nation-building pedagogies may be seen as one version of colonial complicity whereby a group of people has been excluded because of 'race'/ethnicity. In the Nordic whiteness discourse created in Sweden in the 1930s, race biologists constructed distinctions between the 'racial characters' of the Swedish nation. The most prominent researcher, Herman Lundborg (1868-1943), attracted a great deal of attention both in Sweden and abroad. One of his projects involved creating a typology of the racial characters of the Swedish nation (Zippel 2009). One result of Lundborg's work is The Racial Characters of the Swedish Nation, a book with a series of photographs aiming at visually representing the racial characters of the Swedish people. 


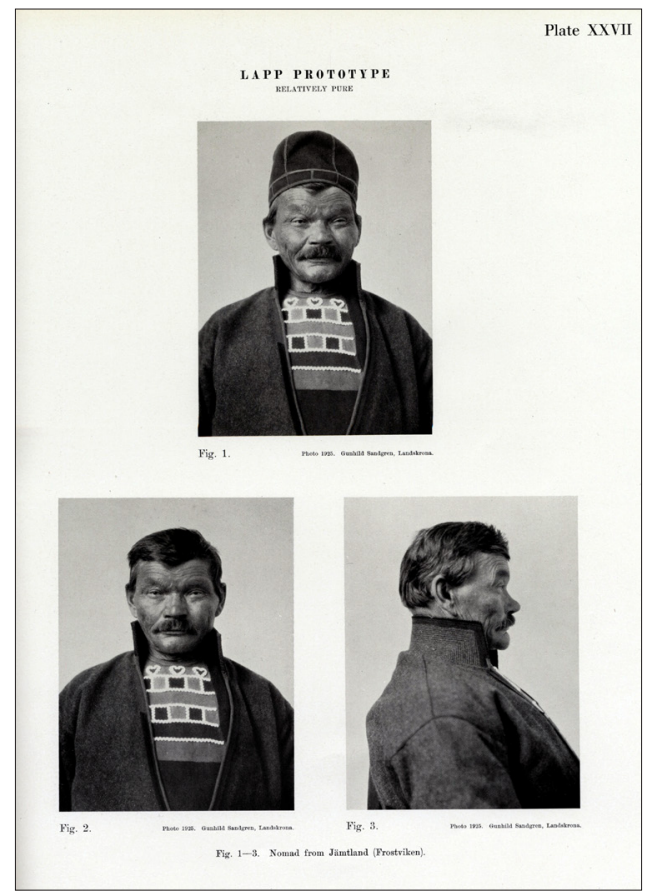

Figure 1. Lapp prototype, illustration in Herman Lundborg and F. J. Linders's The Racial Characters of the Swedish Nation (1926).

When viewed with perspectives drawn from Nordic Critical Whiteness studies and the concept of 'colonial complicity', the exclusion and othering of the Sami and Tornedalians in Sweden may be described as a construction of 'others within'. This practice involves a racialisation of Finnish ethnicity inspired by discourses of race biology which construct Finns as being different from the Nordic, 'Aryan' racial type (Kemiläinen 1998; Laskar 2008). By analogy with Said's analysis of how Western attitudes towards the Middle East have been shaped by 'Orientalistic', Eurocentric prejudices and stereotypes, the specific areas where the 'others within' live, may be conceived of as domestic, Nordic Orients (Said 1978; Ekström \& Gerholm 2006). One common aspect of the concepts of 'the other within', 'the Nordic Orient', 'internal colonialism' and 'vernacular cosmopolitanism' is that they are based on a recognition of the need to consider the situation 'at home' when mapping colonialism and post-colonialism. This may involve the kind of reshaping of national culture and identity discussed by Bhabha in his exploration of the notion of 'vernacular cosmopolitanism' presented in the preface of the 2008 edition of The Location of Culture (Bhabha 
2008: IX-XXV). Bhabha draws attention to present-day cultural revision, going on by pointing out that: "Increasingly, 'national' cultures are being produced from the perspective of disenfranchised minorities" (ibid.: 8). This revision is performed by migrant authors and ethnic and linguistic minorities within the nation states. Bhabha's model of the contemporary remapping of national culture involves a critique of both modernity and homogenising nation-building:

$[\mathrm{P}]$ ostcolonial critique bears witness to those countries and communities - in the North and the South, urban and rural - constituted [...] 'otherwise than modernity'. Such cultures of postcolonial contra-modernity may be contingent to modernity, discontinuous or in contention with it, resistant to its oppressive, assimilationist technologies; but they also deploy the cultural hybridity of their borderline conditions to 'translate', and therefore, reinscribe, the social imaginary of both metropolis and modernity. (ibid.: 9)

When considering the difference between the temporality of modernity and the present time of remapping, which Bhabha calls 'a revisionary time' (ibid.: 10), a major significance is attached to the role of agency in the form of the creation of affiliations among disempowered groups. Bhabha frequently uses the term 'minorities'.

Pohjanen and Kenttä's Meänkieli grammar book was published in 1996, before Meänkieli was officially acknowledged as a minority language in Sweden. Ever since the 1970s, Bengt Pohjanen has repeatedly highlighted that the Tornedalian Finnish language was stigmatised and marginalised in a Swedish nation-state context. The fourth stanza of the well-known poem Jag är född utan språk (I was born without language), first published in 1973, reads:

I was whipped at school

into language, clarity

nationality

I was whipped to contempt

for what was mine

the want of language

and the border. (author's translation)

This poem has been reprinted a number of times, for example in a Meänkieli grammar book in Swedish by Pohjanen and Eeva Muli, Meänkieli rätt och lätt. Grammatik i meänkieli [Meänkieli right and easy: Meänkieli grammar] (Pohjanen \& Muli 2005). 
The official recognition of Meänkieli as a minority language in Sweden is important for the creation of a positive Tornedalian cultural identity. One aspect of language is that it functions as an ethnic marker, which can be problematic when ethnic minority status has been stigmatising for the minorities in question. When discussing this theme from the vantage point of the FinnoUgric Kven population in northern Norway, Anna-Riitta Lindgren emphasises that the recognition of the language of a minority is vital for positive identity formation (Lindgren 2003: 111). She makes the point that as the language of the Kven people in Norway was not recognised as an autonomous language, it would always be compared with the norm for Finnish in Finland and found to be inferior. The same argument may be applied to Meänkieli, which in some respects may be described as a Finnish dialect, but which also differs from Finnish in Finland due to influences from Swedish.

\section{A TORNEDALIAN NEGRO: THE USE OF FIGURATIVE LANGUAGE FROM DISCOURSES OF SLAVERY AND RACISM}

The Finnish term 'rättipäät' is a pejorative slang word used to denominate 'Arabs'. Literally it means 'ragheads'. The poem Rättipäät is one of the texts in Meänkieli reproduced in Meänkielen kramatiikki [Meänkieli grammar] by Matti Kenttä and Bengt Pohjanen. ${ }^{1}$ On the back of the cover there is a text that comments upon the increase in the use of Meänkieli, previously called Tornedalian Finnish, during the decade before 1996 when the book was published: "Koo on kramatiikki niin oon jo kieli, jolla oon säänöt. Nyt meänkieliki toela kuuluu muitten kielitten roihkan." [When there is a grammar there is also a language that has rules. Now Meänkieli also has its place among other languages.] This statement testifies to the performative quality of the grammar book and its aspiration to consolidate the status of Meänkieli as a language of its own. Meänkieli is shaped by a Swedish-Finnish linguistic continuum where Finnish and Swedish intermingle in the borderscape. The emphasis on Meänkieli as a language of its own may be interpreted as a celebration of the Third Space of enunciation and ambivalences which refute notions of cultural purity (cf. Bhabha 2008: 54-56). Meänkielen kramatiikki consists of sections numbered from 1 to 12.22 . The content of the sections varies, from the presentation of a historical backdrop, performative negotiations of the status of Meänkieli, the presentation of orthography, vocabulary, phonemes and parts of speech, to specimens of writing in Meänkieli. These specimens are found in section 12 and they range from an example of the seventeenth century peasant poet Keksi's poetry (12.4., p. 140) to contemporary texts by Bengt Pohjanen and 
other authors. The poem Rättipäät, numbered 12.16, is one of these specimens. The name of the respective authors and the year of publication for the first time are printed below each specimen. Rättipäät, for example, was published for the first time in 1987 (Pohjanen \& Kenttä 1996: 153).

Rättipäät

Nyt aurinko nousee meile, yli mailman neekereile.

Rättipäät ja mutakuonot: ei niil' ole ajat huonot.

Nyt oon tullu meän vuoro, laulaa vähemistön kuoro, kaikkialla mailmassa: Lontonissa, Pajalassa.

Herraskansat, äitipuolet, niilä vasta suuret huolet, niilä vanhaa oon jo kieli, meilä herräämässä mieli.

Net laulunsa oon laulanheet, jo Dallaksensa elähneet.

Niil' ei ennää kelpaa mikhään, sanova varsin: s'ole mithään!

Tuokaa nautintoja lissää, väkivaltaa naisen nissää. Met niistä rahhaa saama ko met tätä mailmaa jaama.

But where is our onkel Sam, arbetskraften den ju försvann. Tyhjinä oon herrain kassa.

I am coming back now massa!

Toppaamapa laulu tämä, annan kehotukset nämä:

Emmä anna ennää perhiin, taistelemma vaikka verhiin. 
English translation: ${ }^{2}$

Ragheads

Now the sun rises for us, over the negroes of the world.

Ragheads and mudfaces; they don't have bad times.

Now our time has come, to sing in the choir of minorities, all over the world:

in London and in Pajala.

Masters, stepmothers, they indeed are in great trouble, their language is really old, our spirit is rising.

They have sung their songs, and lived their Dallases.

For them nothing is good enough anymore, they say: it doesn't matter!

Bring more pleasures, violence and women's teats. ${ }^{3}$ We make money from them when we divide this world.

But where is our onkel Sam, ${ }^{4}$ arbetskraften den ju försvann. ${ }^{5}$ The masters' cash boxes are empty. I am coming back now massa!

Let us finish this song, I present these urgent requests:

We will no longer let go, we will fight even if it comes to bloodshed. (translation by Anne Heith) 


\section{'RAGHEADS' AND 'MUDFACES': PROVOCATION AND REMAPPING OF NATIONAL COMMUNITY}

The title Rättipäät is an offensive term that connotes the use of 'Keffiyehs', a headdress fashioned from a piece of cloth. Traditionally this kind of headdress is worn by Arab men. From the vantage point of poetics, Rättipäät exemplifies a synecdoche, that is, a rhetorical figure in which a part is substituted for the whole. There is an evident connection between the figurative word, 'rättipäät', and what it designates, namely Arab men wearing 'Keffiyehs'. The effect of a synecdoche as a stylistic phenomenon depends on whether or not it is expected in its context (Preminger \& Brogan 1993: 1261). As pejorative language is not the kind of terminology one expects to encounter in a grammar book, the effect is strong, even provocative. There is an analogy to the term in the third line of the first stanza, in which 'rättipäät' is juxtaposed with an equally offensive term 'mutakuonot', literally 'mudfaces', a term used to denote black people. From the perspective of the entire poem, the term 'rättipäät' functions as a metonymy, a figure in which one word is substituted for another on the basis of some material, causal or conceptual relation (ibid.: 783). In the case of the poem, a conceptual relation is established between the 'rättipäät' mentioned in the title as well as the first stanza, and the 'negroes' (neekereile) and 'mudfaces' (mutakuonot) also of the first stanza, the minorities (vähemistön) of the second, and the work-force (arbetskraften) and the lyrical 'I' of the sixth stanza. One thing these categories have in common is that they connote disempowered and marginalised people. In the case of the pronoun ' $I$ ', this effect is achieved through identification and self-ascription. ${ }^{6}$

The poem represents hybridity which in Bhabha's words may be described as "a difference 'within', a subject that inhabits the rim of an 'in-between' reality", a "borderline existence" (cf. Bhabha 2008: 19). The subject positions exemplified in the poem are those of the Swedish Tornedalian Finnish ethnic and linguistic minority and those of migrant groups living in metropolitan centres. These categories connote the existence of 'difference within' by refuting notions of cultural purity. The main theme of the poem is that of vernacular cosmopolitanism, as it stages an emerging imagined community of the rural ethnic minority of Swedish Tornedalian Finns and migrants in metropolitan spaces. This exemplifies a new way of conceiving the nation and categories such as belonging and identity. 


\section{PERFORMING HYBRIDITY}

The term 'rättipäät' involves both a double vision and a performative move, as the pejorative denomination is being appropriated and recoded in a vision of agency and vernacular cosmopolitanism. As mentioned above, Rättipäät is printed in a grammar book written in the Meänkieli language. The publication of this book is in itself a performative act which partakes in the remapping of nation and culture. The role of language has always been a major theme, both in the suppression of ethnic and linguistic minorities, in present-day articulations of post-colonial critique and in visions of vernacular cosmopolitanism. The poem consists of seven stanzas of four lines each. Every stanza has a pair of rhyming couplets. Meänkielen krammatiikki is a very unconventional grammar book, when compared to mainstream discourses for grammar production. The language is very informal and it reflects the hybrid, 'pidgin' nature of the spoken language of the border zone. The book includes poems and other specimens of literary writing, not generally found in grammar books. Furthermore, Meänkielen krammatiikki strongly highlights the theme of internal colonialism (cf. Hechter 1975) from the perspective of the colonised. This is evident, for example, in the poem Rättipäät. The title of the poem clearly indicates that the author is concerned with a conscious challenge of notions about political correctness. This is enhanced in the poem itself, where offensive terms are used.

\section{THE DOMESTIC OTHER OF THE WHITE NATION}

The term 'negro', which etymologically denotes the colour black, is particularly charged with symbolic meanings, both in colonial and postcolonial discourse. This is related to the role of racial markers in the construction - and deconstruction - of cultural thresholds, which are activated for the purpose of marking ethnic and cultural identities. ${ }^{7}$ It is not hard to find examples of the use of racial stereotypes in the construction of Swedish cultural identity. This theme is explored in studies of Orientalism in Sweden (Mattis 2005; Ekström \& Gerholm 2006). Terminology such as 'Orientalism in Swedish' and 'The Orient in Sweden' (author's translations), involves an appropriation and adaption of Edward Said's analysis in Orientalism, for the purpose of highlighting the existence of Orientalist ideology in Swedish cultural production (cf. Said 1978). Orientalist ideology is manifested, for example, in racial stereotyping. In this context, the role of blond hair and blue eyes in the construction of the ideal Swedish (and Nordic) type has been highlighted in post-colonial critique (Catomeris 2005). However, there are also other vantage points for the analysis of the construc- 
tion of 'others', for example, when the roles of class and status are considered. Ekström in particular points out that certain groups within western societies have been singled out as the 'others' for not fitting into the notion of a western ideal: "single-parent mothers, social-welfare cases and various ethnic minorities may often personify the notion of the threat from within" (Ekström 2006: 21 , author's translation).

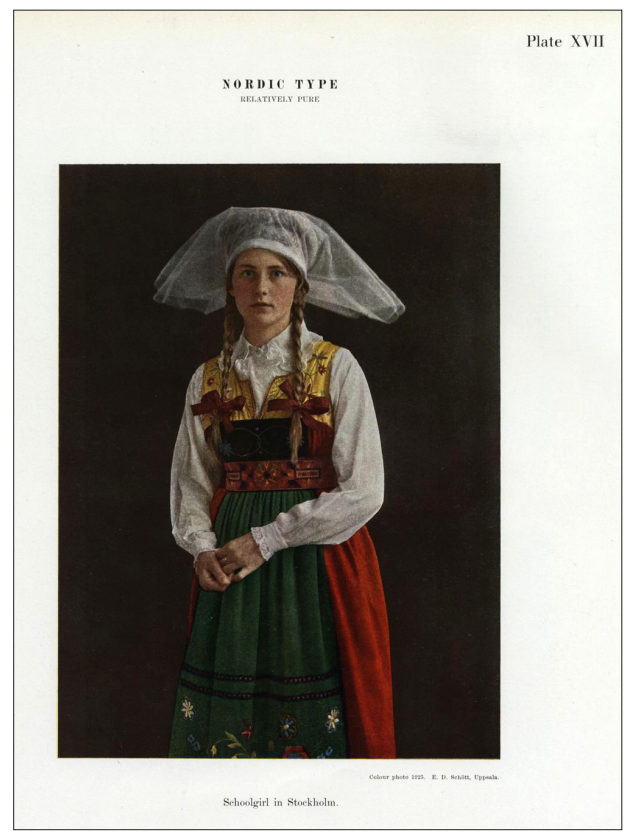

Figure 2. Girl categorised as a Nordic type in Herman Lundborg and F. J. Linder's The Racial Characters of the Swedish Nation (1926).

Another example where the problematic relationship between Swedish national identity formation and race is at the fore, is a study entitled: Kan man vara svart och svensk? (Is it Possible to Be Black and Swedish?) (Jacobsson 1999). The choice of title clearly reflects the role of a symbolic colour-line in the exclusion of groups of people from the imagined Swedish national community. Given this backdrop, the deployment of the term 'negro' in a poem by the Swedish Tornedalian Finnish ${ }^{8}$ author Bengt Pohjanen involves a confrontation of a cultural threshold, charged with a history of exclusion and racism. 


\section{INCLUSION AND EXCLUSION: ALTERNATIVE IMAGINED COMMUNITIES}

The beginning of the first stanza reads: "Now the sun rises for us, / over the negroes of the earth". The status of 'us' in the poem does not include being part of the imagined community of a nation-state. On the contrary, the use of figurative language from the discourses of slavery and racism in spaces where black and Arab people have been subjected to oppression, directs the reader's attention to the historical exclusion and oppression of the Tornedalian Finnish minority. This is one example of how the emotional content of post-colonialism may be expressed through analogy. This does not imply that the situation of the Tornedalian Finnish minority in Sweden has ever been the same as, or even similar to that of slaves in the U.S.A. or colonised people in Africa, Asia, or the Caribbean. Rather, the figurative language of the poem is deployed in order to represent a history of inequality, from the perspective of someone who identifies with people who have been oppressed and marginalised. In this poetic discourse the 'negroes' and the 'ragheads' who are subsumed in the pronoun 'we', function as signifiers of the oppressed. The effect is that a metonymic relationship is established between these categories and the Tornedalian Finns. The pronouns 'we' and 'they' function as representations of exclusionary and inclusionary practices in a transforming space. The pronoun 'we' refers to the Tornedalian Finnish population. Since the year 2000, this population has the official status of being a historical ethnic and linguistic minority in Sweden.

\section{L'UGRITUDE}

In a later book on the history of Tornedalian Finnish literature, Pohjanen makes a similar connection by coining the term 'L'Ugritude', which is a combination of the words 'Négritude' and 'Ugric' (Pohjanen \& Johansson 2007; Heith 2009b). Paradoxically, the effect of the established relationship is that the categories are represented as different and similar at the same time. The use of the ' $n$-word' and other pejorative terms that are metonymically linked to the category of the Swedish Tornedalian Finns, takes on a specific significance when we take into consideration that the terms are used for the self-definition of an ethnic group. When discussing the construction of ethnic identities, the Norwegian anthropologist Fredrik Barth emphasises that the features "that are taken into account are not the sum of 'objective' differences, but only those that the actors themselves regard as significant" (Barth 1998: 14). In the case of the poem Rättipäät, Bengt Pohjanen exemplifies an actor who chooses to high- 
light similarities between groups that have been disempowered and oppressed through their exclusion from western modernity along race lines. Being himself a Swedish Tornedalian Finn, this involves a statement about Swedish colonial complicity and social hierarchisation through the establishment of metonymic relationships between 'negroes', 'ragheads', 'mudfaces', and Tornedalian Finns.

\section{"NOW OUR TIME HAS COME"}

The post-colonial time and space of the poem are indicated by the fact that it is situated in the present time, which is one of resistance and solidarity. The second stanza reads:

Now our time has come, to sing in the choir of minorities, all over the world:

in London and in Pajala.

In spite of the use of figurative language from discourses of colonialism and racism, the poem expresses not only a post-colonial awareness of oppression on a global level, but also of resistance. Through the introduction of a contemporary urban space, London, which is juxtaposed with the Tornedalian community Pajala in northern Sweden, the space represented becomes that of the presentday globalised world. This reflects the changes of geocultural configurations which have taken place, from the time of homogenising nation-building, to that of present-day globalisation. This new geopolitical configuration provides a backdrop of the poem's vision of the multiethnic, transnational choir. Moreover, this provides a conceptual framework for new notions of identity, which allow for cross-cultural exchange within an emerging post-colonial and globally transnational world. One theme of the poem, illustrated by the second stanza, is the exploration of new options for identity formation, in a space that implies that thresholds bordering the Eurocentric, imagined, racially homogeneous west have been crossed.

\section{LINGUISTIC DIVERSITY}

All of the stanzas are in Meänkieli except the sixth one, which is in English (line one and four), Swedish (line two) and Meänkieli (line three). Thus the poem is literally multilingual. The domination of Meänkieli and the inclusion of phrases in Swedish and English may be interpreted as a strategy for signalling that the time has come for Meänkieli to claim 'its place' as a language 
on parity with other languages in a globalised, multilingual world. All the lines of the sixth stanza contain linguistic markers either of ethnicity, signs of loss or disempowerment. The first line's 'onkel Sam' exemplifies linguistic hybridisation. The phrase may be interpreted as a metaphor of neo-colonialism. It furthermore draws attention to the globalisation of economy, which is connected with local unemployment, and a dispersal of the work force (line two), and economic deficiency (line three). ${ }^{9}$ The question of the first line asks where 'onkel Sam' has gone. This is paralleled by the disappearance of the work-force of the second line ("arbetskraften den ju försvann") and in the third line by "the masters' empty cash-box ("Tyhjinä on herrain kassa"). Thus, causality is invoked between decisions made by multinational enterprises, a loss of job opportunities and economic stagnation on a local level. These images of relationships between the global economy and local economic stagnation are countered by the fourth line's "I am coming back now massa!", which connotes agency and protest from the part of the dispossessed, represented by the 'I' of the poem. The emotional intensity of the response is emphasised by the exclamation mark and the use of the word 'massa', slang for 'master'. Stylistically the word 'massa' connotes linguistic creolisation and slavery. The poem Rättipäät is written in the form of a dramatised speech in which the lyric 'we' expresses an interpretation of the present situation, which is seen as a time of positive change for those minorities subsumed by the pronoun 'we'.

\section{REVITALISATION}

Language is an important theme of the poem, not by direct reference but through Pohjanen's deployment of different languages, which involves a statement about the status of Meänkieli. One function of language is that it plays a major role in marking differences in the constructions of cultural identities and for the creation of 'groupness' (Edwards 2009). The importance of establishing a language that is generalised and normalised, a literature of one's own, and institutions for the production of works in the language of a particular ethnic group, are general elements of the post-colonial struggle seen all over the globe (cf. Chatterjee 1993: 9). This is also the case when it comes to Swedish Tornedalian Finnish ethnic mobilisation. One vital element of this process is the production of suitable educational literature which may contribute to the strengthening of the position of the Meänkieli language. This is one backdrop of the Meänkieli grammar books, co-authored by Bengt Pohjanen (Pohjanen \& Kenttä 1996; Pohjanen \& Muli 2005). Both grammar books contribute to constructing a colonial past and a present where compliances with colonialism 
co-exist, and enter into agonistic relationships with anti- and post-colonial, alternative modes for interpretation.

Meänkielen krammatiikki was published by Kaamos, a publishing-house with a Meänkieli profile started by Bengt Pohjanen. It presents the historical background to the specific present-day transnational area Meänmaa (literally 'our land'), which covers parts of Sweden and Finland. One section is entitled Tsarin viiva, which means 'the line of the tsar'. The expression refers to the establishment of the border after the war between Sweden and Russia. According to folk legend, the border was the result of a line that the Russian tsar had drawn on a map to indicate where the border should be (Pohjanen \& Kenttä 1996: 13). The authors particularly comment upon the shame connected with belonging to the Meänkieli-speaking minority, which resulted in people changing their Finnish names into Swedish ones and choosing to use Swedish instead of Tornedalian Finnish. Language loss is an important theme related to bordering practices whereby attempts have been made to create a homogeneous Swedish culture. Today, all the minority languages of northern Scandinavia are marginalised, stigmatised and endangered as a result of modernisation processes and assimilation politics (Pietikäinen et al. 2010: 6). In Sweden, the Tornedalian Finnish language was considered a 'foreign' language after the border had been established in 1809 (Huss 1999). The sense of cultural inferiority described by Pohjanen and Kenttä reflects a major theme of postcolonial studies, discussed by Hechter as an element of internal colonialism (Hechter 1975: XVII). Still the content of Meänkielen krammatiikki reflects a 'decolonised mind' (cf. Smith 2008) as the history of marginalisation is used as a backdrop to a practice that may be described as a combination of post-colonial speaking back, deconstruction and of present-day selfassertion and empowerment. One instance of this is the positioning of the Meänkieli language on an equal footing with the Finnish language, in an illustration that shows the kinship of Finno-Ugric languages in a language tree (Pohjanen \& Kenttä 1996:16).

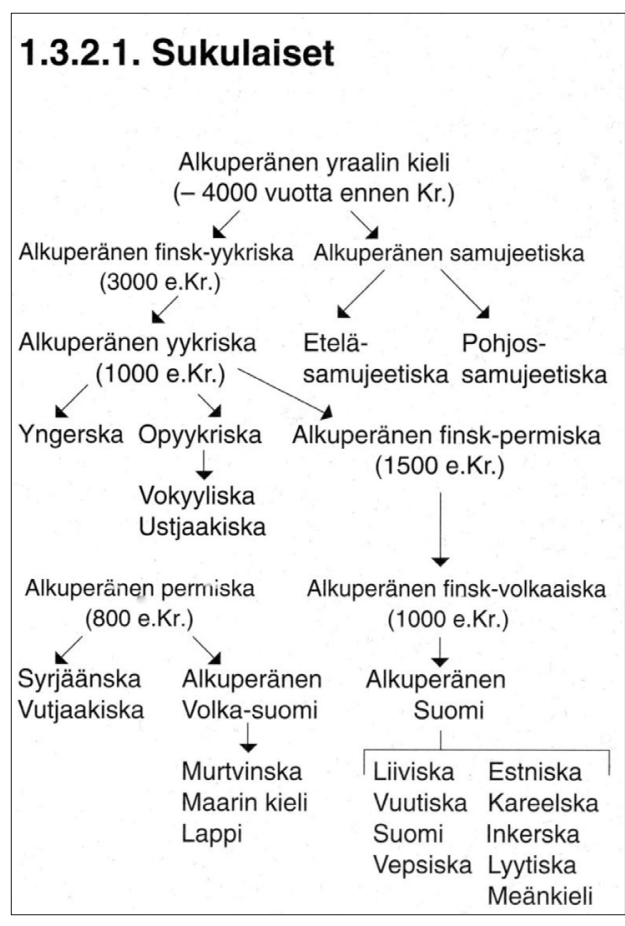

Figure 3. Illustration from Meänkielen krammatiikki that represents Finnish (Suomi) and Meänkieli as equals. 
There is a deliberate reversal of value-coding when Meänkieli is characterised as a "fiini kieli" in a title that reflects the hybrid nature of Meänkieli. ${ }^{10}$ This involves a mixture of Finnish and Swedish linguistic elements (ibid.: 17). This practice of mixing is one of the reasons why Tornedalian Finnish has historically been held in low esteem and why notions of cultural inferiority have been connected with Tornedalian culture. In the novel Populärmusik från Vittula (Popular Music from Vittula), Mikael Niemi describes the socialisation of schoolchildren into a culture of poverty and exclusion from 'proper' Swedish and Finnish culture when enumerating what the children were taught at school: "We spoke broken Finnish without being Finns, we spoke broken Swedish without being Swedes. We were nothing" (Niemi 2000: 50, author's translation).

\section{RESISTANCE}

The theme of the poem Rättipäät emphasises the dynamics between prevailing colonialism, represented in the present by discrimination of black and Arab people who have migrated to the hearts of the old empires. ${ }^{11}$ The theme furthermore highlights anti-colonial resistance. This present-day resistance implies a claim for groups that have been marginalised due to ethnicity, race or minority status, to become recognised and acknowledged. It must be underlined that the term 'negro' is not deployed pejoratively here. Rather, the use of the term exemplifies a strategy similar to that previously employed by the Négritude movement (Heith 2009b: 49). The members of the movement believed in a strategic use of a common black identity and a shared heritage in the fight against colonial political and cultural domination. Today, notions of race and blackness may be used strategically (cf. Lundahl 2005) in challenging colonising discourses and practices. However, although Pohjanen uses allusions to slavery, race, disempowerment, blackness and resistance, it is important to keep in mind that the poem does not depict black subjectivity in the mode of writing which relates to the African diaspora as experienced by people of African descent. ${ }^{12}$ Rather, Pohjanen uses the concept of 'blackness' in the poem metaphorically, for the purpose of establishing metonymic relationships between historically marginalised and racialised groups.

One important aspect of the Négritude movement is that it advocated cultural difference in making a point of being opposed to assimilation with the dominant culture and by reclaiming the word 'negro' as a positive term (Heith 2009b: 49). This strategic dimension is important as a backdrop to the use of the term in the poem Rättipäät, where it is used symbolically in the first two lines of the first stanza: "Now the sun rises for us, / over the negroes of the earth". 
Here the word 'negro' is used metaphorically to denote suppressed groups and minorities. This is emphasised in the second stanza's mentioning of "the choir of minorities". The sun that rises (first stanza), the choir of minorities (second stanza), the statement "I am coming back now massa!" (sixth stanza) and the final statement "We will not relinquish anymore / we will fight even if it means bloodshed" (last stanza) function as a series of metaphors that point toward a single theme, namely that the time of unity among minorities and protest towards oppressors has come. The poetics of the poem implies that a discourse of slavery and colonial oppression is deployed in order to provide figurative language for the representation of the oppression of the ethnic and linguistic Tornedalian Finnish minority in Sweden. This in itself exemplifies an appropriation and adaption characteristic of post-colonial discourse.

There are many examples of how references to black skin colour are used symbolically in present-day cultural production to denote marginalisation, for example, in urban youth cultures (Heith 2008: 635). One example from Latin American ethnographic studies is provided by David Guss's account of the figure of the 'black' saint San Juan Congo. In this, Guss clearly shows how metaphoric links are established between blackness, on the one hand, and poverty, oppression and marginalisation on the other. When Guss finally gets to see the figure of the saint in real life, he is stunned when he sees the light-skinned figure with Caucasian features and curly blond hair. Eventually he realises that:

[T] he issues of blackness signified by San Juan Congo were much more profound than simple pigmentation. [...] For the blackness represented here was that of poverty and oppression. It was the economic and social marginalisation that had defined the African condition since the arrival of the first slaves [...]. (Guss 2000: 56) ${ }^{13}$

The pervading positive tone of the poem Rättipäät is achieved by its metaphors that connote positive change and solidarity - the sun that rises and the time that has come for the choir of minorities to sing together all over the world. These instances of figurative language represent that change (which implies that oppression and marginalisation have been replaced by agency) is to take place. The metaphor of the singing of the choir of minorities is particularly interesting as it addresses the issue of 'unity in diversity' in the shape of vernacular cosmopolitanism.

Rättipäät is a poem that provides a vision of a positive future for those who have been oppressed by presenting a vision of community and agency. ${ }^{14}$ Thus it provides a counter-image to representations of dispossession and disempowerment. The rhetoric of the poem mimics that of popular movements that competed for followers in the Torne Valley and the northern region during 
the period in which the modern welfare state evolved. Historically, popular revivalist movements have attracted followers in this region. When the Social Democratic movement began to have an impact on peoples' minds in the 1930s, there was a competition between politically motivated visions for social change and religious visions which were more focused upon eternity and life after death (Lundmark 1985).

\section{LITERARY WRITING AND BECOMING TRANS-CULTURAL}

The vision of Rättipäät, of empowered minorities joining globally in resistance, may seem romanticised. Certainly it is in stark contrast to those political analyses which have pointed out that there is no essential or necessary ground for political affiliation or alliance between various oppressed groups (cf. Laclau \& Mouffe 1985). However, strict political analysis is not the genre of Pohjanen's poem. Rather, it exemplifies literary writing that echoes the rhetorical traditions of local, popular, utopian, visionary discourses. Moreover, there is a link to an anti-colonial, popular, visionary rhetoric, which is formulated in the work of Franz Fanon. In the seminal books The Wretched of the Earth and Black Skin, White Masks, Fanon advocates popular anti-colonial resistance. As part of this he expresses the notion that people throughout the world, who have been dominated by colonial rule, share collective experiences, and in some sense partake in the same struggle for emancipation and justice (Fanon 1968; Fanon 2000). This theme is also explored in the studies of 'migrant literatures' (Merolla \& Ponzanesi 2005). One effect of migration is the re-imagination of space "both in the language of memory and in the political future" (ibid.: 15). This involves that metropolitan cities, such as London, may become part of a wider trans-cultural web, and that writers in the metropolitan cities re-conceptualise themselves by recurring to a trans-cultural consciousness (ibid.). This type of conceptualisation has been appropriated and adapted by Bengt Pohjanen in the poem Rättipäät, in which the transgression of symbolic and concrete meanings attached to notions of urban and rural, centre and margin, function as elements of the vision of the choir singing in unison in London and in Pajala. This is a new way of re-conceptualising a trans-cultural consciousness in a present-day transnational space. 


\section{ALLEGORY}

Rättipäät may be read as an allegory of colonialism. Pohjanen's use of figurative language describes a situation that symbolically refers to various forms of colonialism and oppression (internal colonialism, neo-colonialism, slavery). According to Ashcroft, Griffiths and Tiffin, this kind of allegory may function as a counter-discourse as the use of the allegorical form may replace monolithic traditions with a cross-cultural pluralism (Ashcroft, Griffiths \& Tiffin 2009: 7-8). In the poem Rättipäät the small Tornedalian town of Pajala and its inhabitants are opened up to a perspective that places them in a globalised post-colonial context. Through this, the poem performs a powerful criticism of internal colonialism in Sweden. When Ashcroft, Griffiths and Tiffin describe the role of allegory in this kind of texts, they highlight the following potential:

[A] 'post-colonial' allegory contests and disrupts the narrative assumptions of colonialism, such as the inevitability of 'development', of 'progress', of 'civilization', the dominance of the chronological view of history, the Euro-centric view of 'the real'. By reinforcing the fact that 'real' events occupy various horizons of meaning, post-colonial allegory becomes a common strategy of resistance in post-colonial texts. (ibid.: 8)

\section{CONCLUDING REMARKS}

In the reading of Rättipäät presented in this article, the poem is seen as a performance of Swedish Tornedalian Finnish self-understanding, which implies the proposal of similarities between the Tornedalians and the racialised categories of 'ragheads', 'negroes' and 'mudfaces'. The narrative of the nation plotted in the poem highlights the existence of colonial complicities within a Swedish nation-building context. These may be in the shape of othering and structures that represent a version of internal colonialism. Both kinds of complicities are elements of a national pedagogy, which has excluded and racialised the Tornedalians. Whether this racialisation has the status of being an 'objective' truth, or not, is not a theme of this article. The poem is seen as a specimen of literary writing and, that being the case, its author has the freedom to make whatever statement he wants about the historical situation of the Tornedalian Finns in Sweden and what similarities there may be between various racialised groups on a contemporary global arena. One advantage of the genre of literary writing when it comes to the expression of strong emotions is that a writer of fiction has a freedom that the scientist does not have. This is one reason why literary writing is suited for expressing personal experiences 
in an explicitly subjective way. Rättipäät depicts a strong emotional response to a Swedish culturally homogenising national pedagogy, which has excluded the Tornedalians. The poem also performs a reversal of value-coding when pejorative, racist terminology is used for self-description and the establishment of affiliations between discriminated groups of people in a global space. This involves a symbolic remapping whereby new allegiances are established between national and global minorities. In this respect Rättipäät may be seen as a performance, in-line with the kind of remapping requested by Bhabha:

[W]e must not fail to see how our own intimate, indigenous landscapes, should be remapped to include those who are its new citizens; or those whose citizenly presence has been annihilated or marginalized. Regional movements of peoples within nation-states, and the financial and cultural impact of migrants upon their 'home' communities and societies, should not be neglected in favor of a celebration of diasporic communities. (Bhabha 2008: XXII)

Bhabha highlights the role of emergent minority communities in processes of symbolic remappings that "revise our sense of symbolic citizenship, our myths of belonging, by identifying ourselves with the starting-points of other national and international histories and geographies" (Bhabha 2008: XX). One proposal of this article is that Pohjanen's representation of the emergent national minority community of the Swedish Tornedalians in Rättipäät and its allegiances with international migrants may be seen as a remapping that revises 'our' sense of symbolic citizenship and myths of belonging, by locating the national and international within emerging histories and geographies that provide alternatives to the narratives of homogenising modernity and colonialism.

\section{NOTES}

1 For further information about Meänkieli, see Matti Kenttä and Erling Wande's Meän kielen sanakirja [Meänkieli dictionary] (Kenttä \& Wande 1992) and Bengt Pohjanen's Meänkielen iso sanakirja / Storordbok för meänkieli [A large dictionary of Meänkieli] (Pohjanen 2011).

2 This translation has been approved by Bengt Pohjanen. In an e-mail correspondence he told me that the poem was written in the context of the seminar New Writing in a Multicultural Society arranged by The Royal Swedish Academy of Letters, History and Antiquities (Kungliga Vitterhetsakademien) in 1985. It has been set to music by Torvald Pääjärvi.

3 Bengt Pohjanen has told me that the motives of this stanza are: view on women, violent movies, money and world view. 
4 This line is in English in the original. The spelling ("onkel") has been kept.

5 This line is in Swedish in the original.

6 Of course Pohjanen's use of the pejorative terms "ragheads" and "mudfaces", which are characteristic of racist, xenophobic discourses, may be analysed from a number of vantage points. The aim of this article is not to present a comprehensive analysis of all possible, imaginable dimensions of the use of these terms, but to focus upon the function of the terms in the poem for evoking a history of internal colonialism in Sweden and for proposing alternative transnational, global imagined communities in the spirit of vernacular cosmopolitanism.

7 The role of the 'color line' in the construction of cultural boundaries is particularly fore-grounded by Foster and Froman in an analysis of thresholds of western culture (Foster \& Froman 2002: 6).

8 'Swedish' here refers to citizenship, while 'Tornedalian Finnish' refers to ethnic and linguistic positioning within the historical minority of Tornedalian Finns in Sweden.

9 The reference to "onkel Sam" also carries other connotations, such as the anti-Americanism of certain groups during the 1980s and a critique of global 'Americanisation'. In this context the expression may be interpreted as a metaphor for a dominant superpower that intervenes in various parts of the world without taking responsibility for the consequences of the interventions.

10 The title "Meänkieli - fiini kieli" [Meänkieli - a fine language] includes the Swedish word 'fin' [fine, good, beautiful] and the Finnish word 'kieli' [language]. The spelling of 'fin' is modified in order to reflect local pronunciation [fiini] and the Finnish adjective ending is used [fiini].

11 This is a major theme of Migrant Cartographies: New Cultural and Literary Spaces in Post-Colonial Europe (Merolla \& Ponzanesi 2005).

${ }^{12}$ For an analysis of Black subjectivity throughout the African diaspora, see Michelle M. Wright's (2004) Becoming Black: Creating Identity in the African Diaspora.

${ }^{13}$ Guss also elaborates upon other possible meanings of the denial of the San Juan figure's whiteness, when he draws attention to Venezuela's denial of colour, which implies that a myth of mestizaje has been established. According to this myth the issue of race does not exist in Venezuela (Guss 2000: 56-59). Critical examinations highlight that the myth has resulted in a systematic repression of Indian and African culture and ethnicity. The 'freedom' afforded to people of Indian and African descent in this context of denial, is to deny their racial heritage by becoming 'white', that is, by assimilating and conforming to the dominant culture of European origin.

${ }^{14}$ Generally the word is used pejoratively. Thus Pohjanen performs an appropriation and adaption when he uses the word to denote the community and agency of minorities. This rather romanticised image is common both in popular political and popular revivalist rhetoric. This is true not least of the Swedish context where the Social Democratic Party was connected with various popular movements ('folkrörelser'). Utopian discourse is also common among popular revivalist movements that have emerged in abundance in the north. 


\section{REFERENCES}

Anderson, Benedict 2006. Imagined Communities. Reflections on the Origin and Spread of Nationalism. London: Verso.

Arvastson, Gösta 1999. Inledning. [Introduction.] In: Gösta Arvastson (ed.) Järnbur eller frigörelse? Studier i moderniseringen av Sverige. [Iron Cage or Emancipation? Studies of the Modernisation of Sweden.] Lund: Studentlitteratur, pp. 9-24.

Åselius, Gunnar 1994. The 'Russian Menace' to Sweden: The Belief System of a Small Power Security Élite in the Age of Imperialism. Stockholm: Akademitryck AB.

Ashcroft, Bill \& Griffiths, Gareth \& Tiffin, Helen 2009. Post-Colonial Studies: The Key Concepts. London \& New York: Routledge.

Barth, Fredrik 1998. Introduction. In: Fredrik Barth (ed.) Ethnic Groups and Boundaries: The Social Organization of Culture Difference. Long Grove, Ill.: Waveland Press, pp. 9-37.

Bhabha, Homi K. 2008. The Location of Culture. London \& New York: Routledge.

Catomeris, Christian 2005. 'Svartmuskiga bandittyper' - svenskarna och det mörka håret. ['Swarthy Bandit Types' - Swedes and Dark Hair.] In: Moa Matthis (ed.) Orientalism på svenska. [Orientalism in Swedish.]. Stockholm: Ordfront, pp. 20-55.

Chatterjee, Partha 1993. The Nation and its Fragments: Colonial and Postcolonial Histories. Princeton, New Jersey: Princeton University Press.

Edwards, John 2009. Language and Identity: Key Topics in Sociolinguistics. Cambridge: Cambridge University Press.

Ekström, Simon 2006. Orienten i Sverige. [The Orient in Sweden.] In: Simon Ekström \& Lena Gerholm (eds.) Orienten $i$ Sverige: Samtida möten och gränssnitt. [The Orient in Sweden: Contemporary Encounters and Interfaces.] Lund: Studentlitteratur, pp. 11-40.

Ekström, Simon \& Lena Gerholm (eds.) 2006. Orienten i Sverige: Samtida möten och Gränssnitt. [The Orient in Sweden: Contemporary Meetings and Interfaces.] Lund: Studentlitteratur.

Fanon, Frantz 1968. The Wretched of the Earth. New York: Grove Press.

Fanon, Frantz 2000. Black Skin, White Masks. New York: Grove Press.

Foster, John Burt \& Froman, Wayne J. 2002. Thresholds of Western Culture: Identity, Postcoloniality, Transnationalism. New York \& London: Continuum.

Guss, David M. 2000. The Festive State: Race, Ethnicity, and Nationalism as Cultural Performance. Berkeley \& Los Angeles \& London: University of California Press.

Hechter, Michael 1975. Internal Colonialism: The Celtic Fringe in British National Development, 1536-1966. Berkeley: University of California Press.

Heith, Anne 2008. Invandraren - Främlingen - Negern. Konstruktioner av utanförskap. [The Immigrant - The Stranger - The Negro.] In: Clas Zilliacus \& Heidi Grönstrand \& Ulrika Gustafsson (eds.) Borders in Nordic Literature, Vol. 2. Åbo: Åbo Akademis Förlag, pp. 635-643.

Heith, Anne 2009a. Millenarianism and the Narration of the Nation. Narratives about the Korpela Movement. Journal of Northern Studies, No. 1, pp. 13-29.

Heith, Anne 2009b. 'Nils Holgersson Never Saw Us'. A Tornedalian Literary History. In: Heidi Hansson \& Cathrine Norberg (eds.) Cold Matters, Northern Studies Monographs, Vol. 1. Umeå: Umeå University, pp. 209-221. 
Huss, Leena 1999. Reversing Language Shift in the Far North: Linguistic Revitalization in Northern Scandinavia and Finland. Uppsala: Uppsala University.

Jacobsson, Ingrid 1999. Kan man vara svart och svensk? Texter om rasism, anti-semitism och Nazism. [Is it Possible to Be Black and Swedish? Texts about Racism, AntiSemitism and Nazism.] Stockholm: Natur och Kultur.

Kemiläinen, Aira (1998). Finns in the Shadow of the 'Aryans': Race Theories and Racism. Helsinki: Finnish Historical Society.

Kenttä, Matti \& Wande, Erling 1992. Meän kielen sanakirja. [Dictionary of Meänkieli.] Övertorneå: Kaamos.

Keskinen, Suvi \& Tuori, Salla \& Irni, Sari \& Mulinari, Diana (eds.) 2009. Complying with Colonialism: Gender, Race and Ethnicity in the Nordic Region. Farnham \& Burlington: Ashgate.

Kristiansen, Roald E. 1998. Laestadianismen som religion for kvenene. [Laestadianism as a Religion for the Kvens.] In: Helge Guttormsen (ed.) Kvenenes historie og kultur. [The History and Culture of the Kvens.] Seminarrapport, Nordreisa 19-21 September 1997. Nord-Troms Historielag 1998, pp. 155-166.

Laclau, Ernesto \& Mouffe, Chantal 1985. Hegemony and Socialist Strategy. London: Verso.

Laskar, Pia 2008. Att pussla med finska kranier. [To Busy Oneself with Finnish Skulls.] In: Ord \& Bild, No. 2, pp. 142-149.

Lindgren, Anna-Riitta 2003. Språklig emansipasjon eller språkdød blant kvener og tornedalinger? [Linguistic emancipation or language loss among Kvens and Tornedalians?] In: Reidun Mellem (ed.) Innsyn i kvensk historie, språk og kultur: Seminarrapport, Tromsø, mars 2002. [A Glimpse into Kven History, Language and Culture.] Norske kveners forbund: Troms $\emptyset$.

Lundborg, Herman B. \& Linders, Frans Josua 1926. The Racial Characters of the Swedish Nation. Uppsala: Almqvist \& Wiksell.

Lundahl, Mikela 2005. Vad är en neger? Negritude, essentialism, strategi. [What is a Negro? Négritude, Essentialism, Strategy.] Göteborg: Glänta.

Lundmark, Lennart 1985. Protest och profetia. Korpela-rörelsen och drömmen om tidens Ände. [Protest and Prophecy: The Korpelians and the Dream of the End of Time.] Lund: Arkiv förlag.

Mattis, Moa (ed.) 2005. Orientalism på svenska. [Orientalism in Swedish.] Stockholm: Ordfront.

Merolla, Daniela \& Ponzanesi, Sandra (eds.) 2005. Migrant Cartographies: New Cultural and Literary Spaces in Post-Colonial Europe. Lanham, MD: Lexington Books.

Niemi, Mikael 2000. Populärmusik från Vittula. [Popular Music from Vittula.] Stockholm: Norstedts.

Pietikäinen, Sari \& Huss, Leena \& Laihiala-Kankainen, Sirkka \& Aikio-Puoskari, Ulla \& Lane, Pia (eds.) 2010. Regulating Multilingualism in the North Calotte: The Case of Kven, Meänkieli and Sámi Languages. In: Acta Borealia, Vol. 27, No. 1, pp. 1-23, doi:10.1080/08003831.2010.486923.

Pohjanen, Bengt 2011. Meänkielen iso sanakirja. [A Large Dictionary of Meänkieli.] Överkalix: Barents Publisher. 
Pohjanen, Bengt \& Johansson, Kirsti 2007. Den tornedalsfinska litteraturen: Från Kexi till Liksom. [Tornedalian Finnish Literature from Kexi to Liksom.] Överkalix: Barents Publisher.

Pohjanen, Bengt \& Kenttä, Matti 1996. Meänkielen Kramatiiki. [Meänkieli Grammar.] Överkalix: Förlaaki Kaamos.

Pohjanen, Bengt \& Muli, Eeva 2005. Meänkieli rätt och lätt. Grammatik i meänkieli. [Meänkieli Right and Easy: Meänkieli Grammar.] Överkalix: Barents Publisher.

Preminger, Alex \& Brogan, T. V. F. (eds.) 1993. The New Princeton Encyclopedia of Poetry and Poetics. Princeton, NJ: Princeton University Press.

Rodell, Magnus 2009. Fortifications in the Wilderness. The Making of Swedish-Russian Borderlands around 1900. In: Journal of Northern Studies, No. 1, pp. 69-89.

Said, Edward 1978. Orientalism. New York: Pantheon Books.

Smith, Linda Tuhiwai 2008. Decolonizing Methodologies: Research and Indigenous Peoples. London \& New York: Zed Books Ltd.

Sundelin, Egil 1998. Laestadianismen som arena for kvensk identitet i Nord-Troms og Finnmark. [Laestadianism as Arena for Kven Identity in North-Troms and Finnmark.] In: Helge Guttormsen (ed.) Kvenenes historie og kultur. [The History and Culture of the Kvens.] Seminarrapport, Nordreisa 19-21 September 1997. Nord-Troms Historielag 1998, pp. 104-114.

Vallström, Mikael 1999. Att möta andra. Etnologins praktik och reflexivitetens Konsekvenser. [To encounter others: Consequences of the practice and reflexivity of ethnography.] In: Gösta Arvastson (ed.) Järnbur eller frigörelse? Studier $i$ moderniseringen av Sverige. [Iron Cage or Emancipation? Studies of the Modernisation of Sweden.] Lund: Studentlitteratur, pp. 133-146.

Vuorela, Ulla 2009. Colonial Complicity: The 'Postcolonial' in a Nordic Context. In: Suvi Keskinen \& Salla Tuori \& Sari Irni \& Diana Mulinari (eds.) Complying with Colonialism: Gender, Race and Ethnicity in the Nordic Region. Farnham \& Burlington: Ashgate, pp. 19-33.

Wright, Michelle M. 2004. Becoming Black: Creating Identity in the African Diaspora. Durham \& London: Duke University Press.

Zippel, Katrin 2009. "Learn to see!" Photography in the Service of Race Biology. In: Helmut Müssener \& Per Jegebäck (eds.) Rasen och vetenskapen. [Race and Science.] Uppsala: Uppsala Multiethnic Papers, pp. 23-59. 